\title{
Relations between Financing and Output in the Not-for-Profit Hospital
}

\author{
Jan P. Clement, Ph.D., \\ Dean G. Smith, Ph.D., \\ and John R. C. Wheeler, Ph.D.
}

This review of the literature on the relationships between financing and output in the not-for-profit (NFP) hospital considers the extent of the influence that financing has on the character of the NFP organization and the extent to which the availability of particular types of financing affects outputs. We also investigate whether characteristics of hospital outputs can affect the availability of financing. Our motivation in presenting this article is our view that the capital formation and capital structure of the health care industry are important determinants of the cost, quality, types, and distribution of the services it provides. Further, government expenditures, taxation, and policies toward debt and equity markets can have a significant influence on capital financing and capital formation.

The importance of capital formation and financing is obvious. Cohodes (1983) has detailed the magnitude of the capital question. Over the current decade perhaps over 100 billion dollars will be spent on hospital

Dr. Clement is Assistant Professor of Health Administration in the Medical College of Virginia at Virginia Commonwealth University. Dr. Smith is Assistant Professor of Health Services Management and Policy, and Dr. Wheeler is Associate Professor of Health Services Management and Policy at the University of Michigan School of Public Health in Ann Arbor. 
capital. According to the Prospective Payment Assessment Commission (1987), capital costs continue to increase faster than total costs. Since 1980, capital costs as a percentage of total costs have risen from 6.2 percent to 8.4 percent. Several reasons for this increase are cited, including inflation in the cost of equipment and plant, cost-increasing technological change, and the substitution of capital for labor in the production process. But a fundamental understanding of how to influence capital financing and expenditures while protecting and improving the character of health care services is lacking.

Such an understanding is crucial to a responsible evaluation of several policy debates, currently raging, that are likely to influence the wellbeing of not-for-profit hospitals and their continued ability to provide services. One of the most visible of these debates is whether NFP hospitals deserve to retain their tax-exempt status. Many state and local governments, in particular, are reexamining the decision to grant NFP hospitals exemption from the obligation to pay income and property taxes. Tax exemption and the legal recognition of the charitable purpose of hospitals permit persons making charitable contributions to take an income tax deduction, thereby stimulating the flow of contributions. This challenge to tax-exempt status derives from a perception that NFP hospitals have pulled back from their commitment to provide charitable services and have begun to act very much like commercial enterprises. Some have argued that there are no differences between the operations of NFP hospitals and those of proprietary hospitals, which are not accorded exemption from taxation (Sloan and Vraciu 1983). Others have argued that health care providers in general are no longer motivated by charity or a desire to be of service as much as they are driven by the same profit motive that defines any typical enterprise in our economy (Herzlinger and Krasker 1987).

A second policy debate bearing less directly on the NFP hospital revolves around fiscal federalism and volunteerism-concepts promoted by the Reagan administration. These concepts hold that the expansion of federal government programs has displaced local government and, in particular, private sector support for socially worthy causes. This "crowdingout" of private contributions to social causes by government could be reversed by a reduction in governmental support for these same causes. A reduction in government financing would stimulate private "crowdingin." The existence of crowding-out and crowding-in would be a strong argument for reduced governmental support for social programs. Fiscal federalism and volunteerism applied to the hospital would mean reductions both in government payments for services and in the availability of government funds for asset acquisition. Funds for NFP hospital asset 
acquisition have pretty much vanished; government payments for services are being tightly controlled. The result is that the hospital is searching for other sources of financing for patient care, such as donations for charity care, and for other means of financing asset acquisition, such as debt. Whether crowding-out and crowding-in do occur depends on the motivations of donors and on the response of the hospitals to donations.

A third policy question concerns whether Medicare, Medicaid, and other large purchasers of care will continue to pay the hospital a price that covers the full cost of acquiring assets, including the cost of financing the assets purchased. The cost of financing assets includes the interest expense on debt and the required return to equity. Most third party payers still pay for debt expenses on a cost-incurred basis-a policy that may have influenced the financing and investment decisions of the hospital. Changing the manner in which these expenses are paid for, therefore, will likely influence future investment and financing decisions of the hospital. To the extent that these decisions affect the character of hospital output, a change in capital payment methodology is important. Medicare is committed to a phasing out of cost-based payments for these expenses. The prospective payment prices are to be increased by a percentage representing approximately the average ratio of capital-related expenses to operating expenses experienced by all hospitals. The debate revolves around whether the price increase to cover capital-related expenses should include a component representing the cost of equity capital as well as the cost of debt capital. Assuming all other payments were at average cost, such a policy would generate accounting profits for the average hospital. Failure to cover the full economic costs of financing in the regulated prices would cause the average hospital either to reduce its stock of assets or to increase its proportion of debt financing in the long run, and would likely alter the quantity and types of hospital outputs.

A fourth important policy debate questions whether NFP hospitals should continue to have access to tax-exempt debt financing. This access is believed to have stimulated the use of debt and to have reduced the cost of financing and thereby the cost of providing care. On the other hand, this tax subsidy has reduced government tax revenues and may have stimulated excess capital expenditures by hospitals. From a public policy perspective, the answer to this question depends on the relative social benefits and costs of this tax-free debt. The costs of tax-free debt are fairly easy to conceptualize and measure in terms of tax collections forgone and a reallocation of resources. However, the benefits depend on how access to tax-exempt debt affects the amount and characteristics of the output of the NFP hospital.

All of these policy debates are related to the issue of capital financing 
of the NFP hospital. The answers found in resolving these debates will have an important influence on the capital structure of the NFP hospital and will potentially affect the cost, quality, mix, and distribution of hospital services. Therefore, the conduct of the debates should be based on an understanding of the relationships between financing and the behavior of the NFP hospital.

The discussion in this article concentrates on long-term sources of financing for the NFP hospital. These long-term sources include donations, government grants, and retained earnings as sources of equity, as well as taxable and tax-exempt debt. In addition, some sources of shortterm financing are covered, including lump-sum operating donations, current-period profits, and government grants for the purchase of charity care. The discussion will focus on how the availability and cost of these financing sources relate to several aspects of the output of the NFP hospital, including the quantity, cost, and distribution of hospital products.

At the outset, it is important to note that no studies address all of the policy issues-or even more than one or two, to our knowledge. The bulk of the literature reviewed comes from the fields of economics and finance, with the remainder drawn from more traditional medical care and hospital administration sources. In all cases this literature is relatively recent, with few citations dating from before the mid-1970s and the majority published within the past five years. The many gaps in the literature and avenues for future research are highlighted.

We begin by surveying the literature that describes the behavior of NFP hospitals without considering financing issues. Many of these studies serve as the foundation for further work on financing. The first papers reviewed that concern financing are those that focus on donations as the sole or principal source of financing for NFP firms. Next, we consider the literature that includes both donations and government financing. The subsequent section covers literature that incorporates internally generated funds as a source of short-term and long-term financing. Finally, we look at papers that analyze the implications of debt financing. Throughout this article, we explore the policy relevance of the literature reviewed. A conclusion summarizes some of the findings and policy implications, and suggests areas for future research.

\section{HOSPITAL BEHAVIOR}

Before considering how various sources of financing relate to hospital behavior, we present some of the models developed to describe hospital behavior in general. Most early models of hospitals do not include financing, but do consider many aspects of hospitals' behavior, 
such as their quantity and quality of output, and their level of technology employed. These same aspects of behavior are of interest in models of hospital financing. General models of hospital behavior that do not consider financing serve as foundations for models that do.

Since the focus here is on not-for-profit hospitals, analysis using the usual behavioral assumption of profit maximization may lead to erroneous results. Similarly, cost minimization, the profit-maximization corollary in competitive markets, may not be appropriate, because of both the not-for-profit nature of the hospital and the lack of competition in many hospital markets. The possible inadequacy of traditional profitmaximizing-cost-minimizing economic models in the case of the hospital industry has led to much speculation and research. An overview of the theories that do not involve financing issues is provided here. Subsequent sections introduce models that explicitly include various sources of financing, some of which are based on these more general models.

Among the many overviews of economic models of hospital behavior are those by Davis (1972), Jacobs (1974), and Joseph (1974). Jacobs' review classifies models of hospitals into six types. The first two types of models treat the hospital as a quantity or quality maximizer. These models translate the objective function of the various managers into the goals of the firm. Rice (1966) and Lee (1971), in the specific case of hospitals, and Baumol (1959) and Williamson (1973), for firms in general, are representative of these two types of models. These models generally follow the same structure as traditional economic models, but for profit they substitute total output or a proxy for quality, such as total number of inputs or proportion of labor inputs. Quantity maximization is frequently used as a goal for models of hospitals that involve financing. The result of having this as a goal is typically that the hospital acquires financing for as many projects as possible with no concern for the specific purpose of the project involved other than the production of more output. The characterization of the hospital is limited to the quantity it produces, which is determined by the amount of financing it is able to secure.

Quality maximization is used less often in models that include financing, perhaps because of the difficulty involved with defining quality. While output ordered on the basis of the quantity of labor or capital used, or the labor-capital ratio, can be used as an indicator of quality, financing models have not offered these interpretations.

A third type of model maximizes the joint objective of quantity and quality. This is the type of model used by Newhouse (1970) and Feldstein (1971) to describe, respectively, the price-cost structure of hospitals and hospital price inflation. The joint objective allows Feldstein (1971) to trace much of the increase in costs and prices of hospital inputs from the 
demand for the increasingly higher quality of care provided by hospitals. While the methodology employed in these models is not generally found in financing models, the predictions regarding hospital costs and prices are often cited and used as a basis for comparison.

The standard objective of profit maximization has been applied to hospitals by Davis (1972). While maximizing quality may be the "true" objective of the hospital, maximizing net cash flows can be considered an intermediate step to maximizing quality. These cash flows can be used to purchase new equipment or better facilities, thus satisfying the final objective. As will be mentioned in a later section, this objective has also been used to explain the more recent issue of "cost shifting," which stems from hospitals' discretion in accounting and pricing practices and in their use of profits. Danzon (1982) and Dittman and Morey (1981) have developed models, also based on profit maximization, to explain the presence of cross-subsidization of services within hospitals. Harris (1979), however, derives similar results in assuming that hospitals maximize social welfare.

Pauly and Redisch (1973) characterize the hospital as an exchange institution that maximizes the profits of the doctors instead of the hospitals' profit. Since doctors control many of the patients' decisions concerning the joint production of physician and hospital services, doctors can maximize their own net income by efficiently using the hospital as an input. The exchange type of model has financing implications by establishing motivation for conflicts between the hospital and its bondholders. This conflict as well as methods of conflict resolution are discussed in the section on debt financing.

The sixth and final type of model of the hospital is as a trusteemanager exchange organization. Clarkson (1972) describes a behavioral theory of the hospital much like Simon (1978) did for firms in general. This type of model allows for conflicts between the suppliers of financing and the manager of the hospital, and possibly for the resolution of these conflicts. Rose-Ackerman's (1987) model of hospital financing and behavior considers this type of conflict by suggesting that managers and donors may have different preferences for the type of output produced. Financing from specific sources may act as a constraint on hospital behavior.

Each of the six general types of model was designed to explain particular empirical results or observed behavior. Therefore, more than one model may be relevant, depending on what one is interested in knowing or predicting about hospitals. Young and Saltman (1983) and Sloan and Becker (1981) have suggested that an accurate, all-encompassing framework within which to view the hospital may be difficult to describe because of the many different functions and outputs of the hospital and 
because the organizational structure of the hospital itself may be endogenous to the system of constraints imposed upon the hospital. Pauly (1987a) has noted that empirically testing among the many competing theories is extremely difficult.

Again, none of the preceding models deals with issues of hospital financing and the behavior of the hospital under differing financing arrangements. However, some of the papers reviewed in the following sections use the more general models of hospital behavior as a starting point or as a reference. The predictions of the various models of hospital behavior may vary due to differing financing arrangements. This type of comparison among models has not been undertaken and would appear to be a fruitful path for future research.

\section{FINANCING THROUGH PRIVATE DONATIONS}

We begin our review of the literature relating financing to NFP hospital output by considering those studies that focus on private donations as the source of financing. This approach is exemplified by the early work of Weisbrod (1977). Weisbrod conceptualizes NFP firms as entities whose purpose is to provide collective goods that neither the forprofit sector nor the government produces; he considers NFP firms to be extragovernmental providers of collective-consumption goods. Donors perceive the output of the NFP firm as having public goods aspects, that is, as benefiting the community in general. The NFP firm comes about because of concern over the suboptimal consumption of a collective good. Persons donate to establish and maintain the firm because it provides goods that they value. Financing comes mainly from donations by persons who care about the consumption of a particular good, as well as from government subsidies. While this point is only implicit in Weisbrod's work, the firm provides the valued good as a return on the investment of the donors.

Weisbrod's work describes the role of the NFP firm in a donor financing situation. However, he does not address directly the important issues of why people donate and what they expect in return for their donation. In addition, Weisbrod's work does not consider whether the firm has objectives-apart from those of the donors-that might influence behavior.

Becker (1974) earlier developed a model of donations behavior based on the individual's maximization of a utility function that includes the person's own consumption and the consumption of others about whom the person cares. Becker's model predicts that donations are highly re- 
sponsive to income (income elastic) and sensitive to income tax deductibility (price elastic). The tax deductibility of donations lowers their effective price, thereby encouraging donations. Additional donations enable the NFP firm to produce more services.

Several studies have contributed to our knowledge about the price elasticity and income elasticity of demand for donations. Feldstein and Taylor (1976) use data from 1962 and 1970 tax files to explore the price elasticity of demand for donations. Although their estimates vary by year of data and by income and age classes, average price and income elasticities of demand are -1.28 and 0.7 , respectively.

Reece (1979) summarizes the work of Feldstein and Taylor (1976) and others: (1) the income elasticity of demand for contributions is estimated to be less than unity, meaning that a 10 percent increase in income induces an increase in contributions of something less than 10 percent; (2) the price elasticity of demand is estimated to exceed unity in absolute value, meaning that a 10 percent increase in the price of contributions, which might be caused by a change in income tax deductibility, would induce a reduction in contributions of more than 10 percent; (3) there is support for the utility-interdependence hypothesis of Becker; and (4) there are different price and income elasticities for different goods. Reece's own empirical study finds an income elasticity in excess of one. He finds that income tax deductibility is an important determinant of the level of contributions. And he finds little support for the utility-interdependence hypothesis. Reece also finds that the effects vary by the type of donation (to charity, religion, education, politics, etc.), and that the results are very sensitive to empirical specification.

Other investigations of the price elasticity of demand have generally found similar results. Reece and Zieschlang (1985) have generated estimates of the sensitivity of charitable contributions to tax deductibility. Their estimates are consistent with the work of Reece (1979) and of Weisbrod and Dominguez (1986), and indicate a great deal of sensitivity to price and tax deductibility. A very recent reestimation by Feenberg (1987) finds a price elasticity of -1.63 , which provides further evidence that the demand for donations is generally price elastic.

Sugden (1984) focuses directly on the financing of voluntary NFP firms through donations and on the reasons why people donate. His model, a reciprocity model, predicts that people will contribute to the production of a public good in proportion to the level of support provided by others in the community. Further, it predicts that individuals contribute only toward the production of those public goods from which they can derive benefits and not toward other public goods. This conclusion is consistent with Reece's empirical finding of little support for the utility- 
interdependence hypothesis. Sugden goes further than Weisbrod in examining the motivations for giving, but from the perspective of the relationship between financing and outputs, he essentially reaches the same conclusion-that the preferences of the donors determine the output of the firm. Neither Weisbrod nor Sugden considers the possible influence of firm objectives and constraints on outputs or the effects of nondonor financing.

All of the studies reviewed so far in this section have focused on the motivation and expectations of donors. Little work, in fact, has been published that ties the behavior of the firm to these expectations. RoseAckerman (1982) and Weisbrod and Dominguez (1986) are among the first to examine whether or not firm behavior with respect to output affects the supply of donations. Rose-Ackerman starts with a model where NFP managers operate to maximize donations net of fund-raising costs. She develops her theory around the preferences of the donor. In her most sophisticated model, donors value their own consumption and give gifts to charity based upon the output characteristics of the charity, the number of people served by the charity, and fund-raising costs. Donors dislike fund-raising costs but value the productivity of such activities in increasing donations. This model predicts the result found by Weisbrod and Dominguez that fund-raising expenditures will be made up to the point where the marginal net contribution is zero. While Rose-Ackerman's conclusions focus on the effects of fund-raising expenditures on donations, her modeling of donor financing as dependent on some specific output behaviors of the firm represents an advance over previous work.

Weisbrod and Dominguez go a step further in hypothesizing that the supply of donations is positively related to the quality and quantity of output produced by collective-good providers, as well as to fund-raising expenditures. Fund-raising expenditures are hypothesized to have two countervailing effects on the level of donations-they increase contributions by reducing information costs for donors, but they also decrease contributions by increasing the price of giving. In their empirical testing of these ideas, the authors develop a measure of the net price of a contribution as a function of the donor's marginal tax rate and the administrative and fund-raising expenditures of the firm. For hospital firms, their empirical results show that the price elasticity of demand is greater than one in absolute value, indicating again that donors are very sensitive to net price. The total elasticity of donations with respect to fund-raising expenditures, including the effect on price, is not significant. The authors interpret this result to suggest that NFP firms spend money on fundraising up to the point where the marginal net contribution to revenue is zero. Therefore, they may be maximizing total expenditures. Weisbrod 
and Dominguez also find donations to be positively related to the age of the firm, which they speculate may be a measure of the extent to which the firm provides the quality and quantity of output it claims to provide. As was true of Rose-Ackerman, Weisbrod and Dominguez do not consider the effects of specific outputs on the level of donations.

Most of the papers that focus on donations as financing for NFP firms identify a distinct and important role for the NFP hospital in providing public goods. Further, the NFP hospital cannot continue to exist if it does not adequately fulfill its social purpose. The fact that NFP hospitals continue to receive charitable contributions is evidence that they provide public goods. One possible policy implication of this literature is that government should continue to provide some financial support to the NFP hospital, that is, to finance a part of the production of the public good. This support could take the form of maintaining tax-exempt status, which would continue to allow donors a tax deduction. Most studies reviewed report that tax deductibility is an important determinant of the amount donated. Whatever mechanism is established for government support, determination of the level of governmental financial aid should be based on an understanding of the relationship between government financing and private donations. The nature of this relationship is considered in the next section.

\section{PRIVATE DONATIONS AND GOVERNMENT FINANCING}

In addition to accepting private donations, many nonprofit firms receive funding from government. Government funding comes in many forms, including lump-sum grants and transfers, tax-exempt use of property, and others. Cohodes and Kinkead (1984) discuss the role of government in providing capital financing to the nonprofit firm directly, through grants and transfers; indirectly, through loan guarantees; and implicitly, by permitting tax exemption, tax-exempt financing, and income tax deductibility of donations. Although they do not emphasize the relationship between financing and output behavior, they do explain how hospital financing has changed and suggest ways for it to change in the future.

In terms of magnitude, government financing almost completely shifted from direct financing to indirect and implicit financing between the 1940 s and the 1980s. Prior to the 1940s, the government had relatively little involvement in hospital financing. In 1946, the Hill-Burton program was established, providing direct grants and loans for a rapid increase in the capacity and modernization of community hospitals. Lave and Lave (1974) document the effects of this program from its inception until it was 
discontinued in the mid-1970s. Altogether, the Hill-Burton program provided over four billion dollars of government financing for hospitals. Since the end of Hill-Burton, direct government grants and transfers have become a small part of hospital financing.

Indirect financing is accomplished primarily through Federal Housing Administration (FHA)-242 loan insurance. FHA backing reduces the risk associated with loans, and thereby reduces the cost of loans and increases their availability. Implicit financing is accomplished through the granting of tax-exempt status to community hospitals. Tax exemption allows hospitals to sell bonds at lower interest rates and to use land and buildings without the usual cost of property taxes. It also allows people to take an income tax deduction on monies donated to hospitals. Because of the shift from direct financing to indirect and implicit financing, recent government financing effects on hospital behavior should result from indirect and implicit financing. However, most models are based upon direct government financing.

The literature on government financing is closely linked to the literature on donations. From a policy perspective, the issue of whether government financing crowds out donations is very important, affecting decisions about government financing of all types, especially direct financing.

\section{PASSIVE FIRMS}

Like much of the literature on firms financed exclusively by private donations, most discussions of government financing are referring to "passive" firms. Passive firms directly convert funds received into goods or services. Without undergoing any specified decision process, the firm provides goods or services in proportion to the total amount of funding available. An equivalent implied objective of a passive firm could be to maximize the quantity of goods or services provided, subject to a funding constraint. Quantity-maximizing firms do have an explicit decision-making process, but the simplicity of the process may leave it unmentioned.

For passive firms, only the total level of funding is considered; the source of funding is not. Essentially, passive firms provide a single product. If donors or the government want more services of a specific type, they simply provide more funds to the appropriate firm. An assumption that the firm is passive implies that the preferences of the sources of financing are directly translated into the firm's behavior. Given that either donors or the government can provide funds, and that the behavior of the firm is the same regardless of the group providing the funds, the issues are these: does government financing affect donations? and are there op- 
timal conditions of government and donor financing for the provision of goods and services? Most of the literature in this area concerns the effect of government financing (usually by direct grants) on donations. These studies that consider optimal financing conditions, in this case maximum amounts of financing from government and private sources, are noted.

Roberts (1984) provides a theoretical statement of the relationship between donors and the government by separately modeling the behavior of donors and the behavior of the government. Individuals with resources for donations derive some utility from consumption by certain other persons (e.g., the poor). A noncooperative, marketplace solution to bring about consumption by the poor is inefficient, since sharing of the cost of donations (cooperation) could result in a lower price for all donors. An efficient solution is provided by a costless system of taxation, transfers, and tax credits for donations where the government acts as an agent to create cooperation. The result of Roberts' modeling is a complete (dollarfor-dollar) crowding-out of private donations by government taxation and transfers.

Roberts' model of the government implies an inefficient redistribution of funds to the poor with respect to the preferences of the donors. Since the government taxation-transfer process can be independently affected by the preferences of the donors and the recipients of donations, a level of transfers to the poor in excess of the noncooperative and simple government solutions is predicted. The government "overprovides" services from the perspective of the donors, and private donations disappear.

Real dollar amounts of donations to various recipients during the depression and from 1955-1982 are presented in support of the results of theoretical models. In fact, real private donations for direct transfers to the poor have practically disappeared, and indirect transfers to social services, health and hospitals, and civic and public organizations have declined since the early 1970 s.

Roberts is certainly not the only author to consider the so-called crowding-out effect of government financing. Both before and since Roberts' paper, the issues of the government's subsidization of donations and of the substitution of government for the private sector have been widely considered. In recent times the reverse of the crowding-out effect has been an issue. Underlying many of the federal government policies in the past few years has been the assumption that if the government does not provide certain goods or services, then the private sector will respond and provide these services. Crowding-out, however, may be incomplete, and its causation may not work in both directions.

In theoretical models with more than two types of goods or more than two types of people, Schiff (1985) finds that crowding-out does not 
necessarily occur, and more fully specifies conditions under which crowding-out would be expected. Perfect crowding-out may occur when the government offers a close substitute, and when donors are just satisfied or are oversatisfied with the level of services provided.

Bergstrom, Blume, and Varian (1986) extend this discussion by looking not only at incremental changes in donations, but at the initial decision to donate or not. In commenting on Roberts and others, they note that only partial crowding-out is implied since not all persons would be donors. The tax-transfer system collects from all and therefore the preferences of the donors are subsidized by nondonors, but not fully. Government provision of services implies a tax burden and a redistribution of wealth. Not only might there be a direct effect of government substitution of private donations, but there might also be a secondary effect of reducing donations through a reduction in donors' wealth and a corresponding reduction in income inequity.

Steinberg (1987) begins with the usual crowding-out model associated with the public goods approach to government grants, which he modifies to include local governments and the endogeneity of government grants. Within the context of a public goods model, an additional private utility of giving exists separately from the public good provided. In a political equilibrium where voters make decisions on the basis of the amount of the public good provided and of the reactions of the donors, Steinberg shows that it is possible to observe some crowding-out; but it is expected to be incomplete. And in the context of reversal of direction of the crowding-out relationship-the expectation of crowding-in that underlies many recent government actions-donations and local governments will not fully replace the federal government's funding if it is withdrawn.

Weiss (1985) takes a game-theoretic approach to this issue and argues that since the government cannot fully know the preferences of the people, even with a cooperative solution it is possible that some persons will be worse off with government provision of funding or services. He includes a possible reversal of causation of crowding-out. If donors are dissatisfied with the provision of certain services, they may themselves donate-and crowd out government programs.

Abrams and Schmitz (1984) examine data from federal tax returns and find that the level of state government transfers is negatively associated with charitable contributions. The coefficients on transfers in their regression models are statistically significant and imply a crowding-out effect of approximately 30 percent. Schiff (1985) also finds a 30 percent crowding-out for state government expenditures and a higher, 60 percent crowding-out for local government expenditures. Further, government 
spending on welfare programs has a negative effect on private funding for welfare programs, but general funding has an insignificant effect on private funding for welfare programs. A conclusion from these empirical studies is that the crowding-out effect exists and that its magnitude is related to how closely the government spending is considered to be a substitute for donations. With respect to Steinberg's consideration of fiscal federalism, these results would suggest that it is unlikely that decreases in general government funding would result in a compensating amount of private donations.

For businesses, which provide a substantial portion of donated funds, the crowding-in issue is mentioned by Navarro (1988) who includes the years 1981 and 1982 as dummy variables corresponding to periods of decreases in government spending. These years are associated with increases in donations, but they do not imply a complete substitution of donations for government funding. For both businesses and individual donors, however, it may be that the full effects of crowding-out or crowding-in occur over a period of several years.

\section{ACTIVE FIRMS}

The alternative to a passive firm is an "active" firm. Active firms may have an objective other than strict quantity maximization and may react to changes in financing and financing sources differently than passive firms. The behavior of active firms can go beyond providing goods and services to include soliciting donations and deciding which clients receive the output of the firm and how the output is produced. Many of the models of active firms are based upon the general behavioral models discussed earlier.

Steinberg (1986) investigates the behavior of the firm with respect to donations and decisions on expenditures for fund-raising efforts, administration, and provision of services. Funds are received exogenously and generated endogenously as a result of the decisions of the firm with regard to these expenditures. The aim of Steinberg's model is to establish a test of whether nonprofit firms are budget or quantity-ofservice maximizers. Firms are budget maximizers if they solicit donations until the marginal return-the return on the last dollar spent on solicitations -is zero. If firms solicit funds until the net return - the total return on all dollars spent on solicitation is zero-they are quantity-of-service maximizers, since this results in the greatest amount of funds available for expenditures on services.

Steinberg's empirical investigation is interpreted to imply that health firms (mostly hospitals) are budget maximizers-an admitted surprise 
to Steinberg given his impression of the existence of competition in health care markets. The small percentage of funds received through donations and lack of price sensitivity on the part of third party payers are provided as explanations for this result. A more thorough explanation is readily apparent given the time period of the data, 1974-1976. In the preprospective payment era (pre-1983), a lack of price sensitivity on the part of third party payers was explicit in the cost-based system of reimbursement. Expenditures for fund-raising efforts, administration, and provision of services were fully reimbursed. With full cost reimbursement, the result of a marginal return of zero is equivalent to a zero net rate of return. A further implication of cost-based reimbursement is the lack of any incentive to solicit funds in the first place. Imperfections in the reimbursement system and unsolicited donations are two explanations for observing any donations in this time period.

Unfort unately, Steinberg does not examine the effect of exogenously received funds, possibly received from the government, although he includes them in his model. But as he notes, the crowding-out effect in firms that select fund-raising efforts has not yet been considered. For either budget- or quantity-maximizing firms, the receipt of exogenous funds presumably furthers the goal of the firm and is not said to affect decisions. The presence of government funds affects firms' output indirectly through the reactions of donors in the passive models, and directly in this and other active models.

Rose-Ackerman (1983) examines the government spending-donations relationship by including matching programs, the "strings" that come with government grants, and the resulting change in the behavior of the nonprofit firm. She modifies the neoclassical private goods, passive, crowding-out model by considering five factors: economies of scale, asymmetric information, endogenous ideologies, complementarities among the various goods, and matching grants. Each of these factors can lead to increases or decreases in observed crowding-out.

Rose-Ackerman's discussion differs from others in its explicit inclusion of the behavior of the firm. This is most clear in the discussion of endogenous ideologies. Deciding what exactly to produce (or whom to help) is made by the firm and is influenced both by government demands and the response of donors. The government, for example, may require a specific behavior in return for a grant. If this behavior matches the preferences of the firm and donors, the grant may be accepted and donations may increase. If the grant does not match the firms' and donors' preferences, the grant may be rejected or donations may decrease. In either case, the firm makes the final decision on the output produced.

Sloan, Morrisey, Cotter, et al. (1986) model the hospital with par- 
ticular attention given to its efforts to solicit donations. They assume that crowding-out occurs from the donor's perspective. That is, the mere existence of government funding causes people to provide fewer (or smaller) donations. Along with other factors, they examine ways in which the quantity of the hospital's output will change with the existence of government funding. The theoretical result is ambiguous because of the assumption of crowding-out. If the magnitude of the crowding-out is assumed to be negligible, then the result of receiving government funding is an increase in output. This comes about because of the positive effect that increasing output will have on stimulating donations and because of the decrease in the cost of soliciting donations.

Empirically, in a slight simplification of the theoretical model, Sloan, Morrisey, Cotter, et al. find that government grants of the matching type (Hill-Burton) have the effect of increasing donations. They do not find a significant relationship between the tax rate and donations, but this may be due to the level of aggregation of their data.

Our review of the various papers on crowding-out shows that crowding-out exists and that its magnitude depends on the type of government financing, the preferences of donors, and the actions of the firm. Government financing that requires matching funds increases donations, and financing that donors view as a substitute for private financing serves to reduce donations to some extent. If the firm is active, it can work to counteract or exacerbate the effects of crowding-out. It appears unlikely that decreasing government financing results in offsetting private donations. Decreases in government financing result in decreases in hospital financing.

Financing in terms of the tax-exempt status of hospitals is considered by Herzlinger and Krasker (1987), and by various authors in the recent report by the Institute of Medicine (1986). Because many of these latter discussions are inseparably linked with comparisons of nonprofit and for-profit firms, and not with examinations of the source of financing per se, they are included only to the extent that they consider the effects of government financing on hospital behavior. In the context of comparing for-profit and not-for-profit hospitals, an inevitable question is, what does the government receive in return for its subsidy of NFP hospitals? It has been suggested that favorable tax status in an otherwise competitive market allows NFP hospitals to offer services that might otherwise be unprofitable, or to treat sicker patients, or to offer higher-quality care. Rather than dictating behavior, tax exemption not associated with specific requirements may allow a flexibility that permits a socially beneficial range of behavior.

Herzlinger and Krasker argue that the suggested benefits are not 
realized and provide empirical evidence to support their argument. Several letters to the editor in subsequent issues of the Harvard Business Review cast serious doubts on their data and conclusions. What is clear, however, is that tax exemption does permit more discretionary behavior than the usual sources of debt and equity financing. What hospitals decide to do, given choices, is still an open question.

The key word here with regard to behavior is 'permit.' Without requirements to meet in return for its tax-exempt status, it is possible that the NFP hospital can either behave or not behave as society would like hospitals to behave. The policy implication of this discussion is focused on whether or not NFP hospitals should retain their tax-exempt status. In accordance with the theme of this review, an alternative issue would be whether or not specific requirements should be made by the government. A discussion of this issue has not yet occurred.

\section{HOSPITAL PROFITS AS FINANCING}

In contrast to the previously cited papers, some studies recognize that many nonprofit firms have mixed missions linked to the source of financing. More specifically, nonprofit firms are modeled as composites of commercial firms that provide services to paying clients and firms that provide social or public goods. The work reviewed in this section considers the role of the profits earned from paying clients (commercial financing) in subsidizing the provision of services to those who cannot pay or the provision of other public goods. Public goods may be purchased by donations in the current period and may be returns to donations made in previous time periods.

Posnett and Sandler (1986) focus on the optimizing behavior of donors to show that using profits earned from paying clients to subsidize the provision of public goods can be an effective fund-raising mechanism. While many of the conclusions from their model are similar to those from other models of cross-subsidization and cost shifting, the introduction of fund-raising makes a connection to financing not found in some of the papers discussed earlier.

In Posnett and Sandler's model, customers purchase private goods from a passive nonprofit firm. Since a portion of the purchase price is directed toward the provision of public goods, private and public goods are jointly supplied. If the nonprofit firm has no cost advantage over profit-maximizing firms, the price of the joint good provided by the nonprofit firm is higher than the price of the good provided by profitmaximizing firms. However, cross-subsidization may still be an effective 
fund-raising tool if the value attached to the public component of output is higher than its implicit price. Cross-subsidization also works in the absence of competition for clients and when some clients have inelastic demand because of insurance coverage (Harris 1979).

If the nonprofit firm does have a cost advantage, the benefits of joint supply are increased. Under these circumstances, the nonprofit firm can supply the good at the competitive price and produce public goods with the surplus. In addition to obtaining revenues from customers who value public good output, donations can be obtained from individuals who derive no utility from increases in the output of the public good.

Most other authors model an active nonprofit firm in which the NFP firm is a composite of a commercial and a public firm. The roles of output in attracting donations and of donations in producing public good output are examined. James (1983) models an active nonprofit firm that is a hybrid of business enterprise and government yet differs from each. Because the manager selects the quantity of two outputs, his or her preferences determine the type and quantity of output of the firm. This firm receives direct lump-sum donations and donations earmarked specifically for the purchase of current output. Some of the outputs that the manager prefers are public goods and may not be profitable. When the supply of funds is limited, the nonprofit firm subsidizes the production of services that lose money with moneymaking outputs that the manager prefers less or even dislikes. Thus, cross-subsidization is a deliberate long-term management strategy for funding the consumption of unprofitable (loss-making) outputs that managers care about most.

James evaluates the response of the nonprofit firm to changes in lump-sum donations for operations and changes in the prices of outputs. When the firm receives a lump-sum donation, it increases the output of the services that managers prefer and decreases the output of services that they do not like. Similarly, when the competitively determined price of a desirable service increases, its output increases. If the price of a disliked service increases, the output of the desirable service again increases. Although James does not evaluate the effect, per unit of output, of a change in the donation, the fact that the sum of price, donations, and government grants per unit is multiplied by the quantity of each output produced makes a change in this type of donation analogous to a change in price.

Long (1976, 1982a,b), Conrad (1984), and Silvers and Kauer (1986) link the appropriate output behavior of the NFP hospital to its long-term financing, and to donations in particular. They, too, envision the NFP firm as a firm that provides private and public goods. Since the capital contributions of the "ownership" could be committed to an alternative 
opportunity, the return provided by the nonprofit hospital must be at least as great as that provided by the next best alternative. The next best alternative is the return on the risk-adjusted (Conrad 1984) market portfolio adjusted downward to account for the tax subsidy of donations (Silvers and Kauer 1986; see also Sloan, et al. 1988). Competitive returns to equity capital suppliers (donors, but sometimes also taxpayers who supply funds for government grants, and customers who pay more than the economic cost of services; see Long 1976) are in the form of nonpecuniary dividends to the community-unreimbursed education and research expenditures, charity care, and the like.

If the returns provided by the nonprofit hospital are not at least as great as the adjusted market return, donors will invest in the market and will use the return to purchase the social goods directly. "At the margin, the equity investor is indifferent between supplying capital to a for-profit enterprise, where it yields an after-tax stream of dividends and capital gains, and to a not-for-profit firm, where the gains are in non-money terms" (Conrad 1984, 44). Consequently, to ensure that capital will be supplied in the future, the nonprofit hospital must provide returns to the equity capital suppliers. To provide the required returns, profits are used during the time period in which they are generated to produce these community dividends (social and public goods); thus, current-period profits on private goods are used to subsidize public goods.

Long $(1982 a, b)$ also illustrates how nonprofit hospitals with their dual role cross-subsidize public outputs with private profits by seeking an overall-neutral net present value (NPV) portfolio of activities. He says that the board should make specific decisions regarding the provision of social goods, the not-for-profit analogy to authorizing dividends in a forprofit corporation. Since the role of the not-for-profit firm is to preserve capital (as opposed to creating or consuming capital), each profit-making service should be altered to be a zero NPV project. This is done by paying dividends or by reducing prices. Although he finds no fault with crosssubsidization of social goods by private goods, Long feels that nonprofit firms should not cross-subsidize services to paying patients.

By providing social returns-community dividends-the long-run survival of the organization is enhanced, because it maintains its ability to attract new infusions of donor capital. Long, like Posnett and Sandler, recognizes that donors may value the output of social goods differently than the dollar price or cost of such goods. In this case, the provider captures an economic "externality"; its value is measured by the extent to which perceived value exceeds out-of-pocket cost. The provider may receive an even greater value if donors perceive social value (e.g., im- 
proved productivity or longer life) that exceeds the accounting cost or charges of the care given.

In contrast, Pauly (1986) claims that often no relationship exists between output and financing-specifically, from donations-in the behavior of the nonprofit hospital. According to his model, initial donations are received as the result of fund-raising efforts; apparently, donors are not promised any pecuniary or nonpecuniary returns by the fund-raising pleas. It is difficult to believe his contention that it is not useful to examine the reasons why people donate, especially when he models the nonprofit firm as a totally commercial firm. He provides no justification of the initial donations even though, at this initial level of output, output is provided only to commercial customers. Pauly does acknowledge that to elicit donations beyond the initial contributions, something must be promised to the donors. These benefits may simply be engraved plaques, or they may be social goods; he concludes that the amount required is an empirical question. Pauly does not, however, suggest that the nonprofit firm provides any significant level of social good output.

Most of the papers discussed above view profits as necessary for NFPs because they are used to provide social goods during the period in which they are earned. Whether NFP firms should keep profits as retained earnings has not been addressed as thoroughly. Wedig, Sloan, Hassan, et al. (1988) note that increasing profits may come at the expense of providing additional services. Although it may be efficient to retain some earnings to decrease the costs of new fund-raising, Silvers and Kauer (1986) question the appropriateness of retained earnings. Retaining earnings eliminates the opportunity for donors to receive a tax subsidy on new contributions. Pauly (1986) believes that the opportunity cost of forced contributions from paying customers is higher than the return on a market portfolio of assets. It is, therefore, inappropriate for NFPs to retain earnings, especially when voluntarily donated capital is cheap. In a later work (Pauly 1987b), he does state that the exact relationship between returns and donations is an unresolved empirical issue. In contrast to these authors, Long (1976) argues that accounting profits (retained earnings) must be positive to ensure a return of capital. If no earnings are retained, the NFP hospital will be unable to continue providing services in the future; it will also be unable to provide the return on equity (social goods) required by equity suppliers.

The model of the normative behavior of NFP firms that we agree with frames our consideration of two policy issues mentioned earlier: (1) whether NFP hospitals should retain their tax-exempt status and (2) whether NFPs should earn profits from reimbursers. If reimbursers do include reimbursement for equity capital, should NFPs use this profit 
contemporaneously to provide public goods or should they retain some or all of it as retained earnings for future use?

Whether NFP hospitals should keep their tax-exempt status is related to the mix of commercial (private) and social-goods output. The answer to this dilemma is linked to the sources of financing if social goods are purchased or subsidized with private-goods profits in the same period (James 1983; Posnett and Sandler 1986) or if social goods are community dividends (Long 1976, 1982a,b; Conrad 1984; Silvers and Kauer 1986).

Merely providing some level of social-goods output, however, is not a sufficient response. Major policy questions remain concerning the amount required in production of social goods. Moreover, we do not know how these goods should be valued; should their value be measured at the price charged or at the full or marginal cost of producing them? In addition, we do not know if the value of these goods related to the level of equity should equal the return on the market portfolio of assets adjusted for risk (Conrad 1984) and tax benefits (Silvers and Kauer 1986). Or, is there an additional perceived benefit that allows NFP hospitals to return less in dollar terms (Posnett and Sandler 1986; Long 1982a,b)? By measuring the output appropriately, managers can be made accountable to the financing sources and can justify the continued tax-exempt status of NFP hospitals. (For a review of the finance literature regarding conflicts between managers and equity suppliers, see Barnea, Haugen, and Senbet 1985.)

Another policy issue concerns whether third party payers should pay a return on equity to NFP hospitals either directly or incorporated in a price to NFP hospitals. If the normative models by Posnett and Sandler, James, Long, Conrad, and Silvers and Kauer, reviewed in this section, are accurate depictions of reality, then profits increase social goods output. When the price for private goods is not set sufficiently high, or when a return on equity is not explicitly paid to donor capital suppliers, the nonprofit firm does not provide these nonpecuniary benefits. Conrad (1984) argues that the declining availability of donations for hospitals shows that the cost of equity capital for nonprofit hospitals is not zero; donors have not been compensated for their opportunity costs. In addition, he claims that failure to provide a return on equity shifts the payment of that return to debt by increasing the amount, and therefore the riskiness, of debt in the NFP firm's capital structure.

If a return on equity is to be paid, the amount should be the return required by equity capital suppliers. Paying this amount ensures that new infusions of equity capital will be forthcoming. However, as noted previously, the required return and whether some of the return should 
be in the form of retained earnings are unresolved issues. Only after that debate is settled can the form of payment (e.g., cost based, folded into prospective payments) be addressed.

\section{DEBT FINANCING}

Very little work concerning the effects of long-term debt financing is available in the health care literature. Rather, this literature examines the relationship between investment and operating costs, but not the effect of capital financing on investment or output (Anderson, Erickson, and Feigenbaum 1987; Ashby 1984; Sloan and Steinwald 1980a,b; Bentkover, Sloan, Feeley, et al. 1984; Dunkelburg, Furst, Roenfeldt 1983).

Most of the finance literature concerning debt concentrates on whether the presence of debt in the capital structure affects the value of the firm and, consequently, whether there is an optimal capital structure (Taggart 1981; Titman and Wessels 1988; Bradley, Jarrell, and Kim 1984). (Recently, Wedig, Sloan, Hassan, et al. [1988] have shed some light on this issue for hospitals.) When perfect capital markets exist, the investment decision can be separated from the financing decision. The literature examines whether financing source affects the value of the firm given the decision to invest. The key concern, however, is not with changes in investment or output, but with the amount of debt. Debt is relevant because larger amounts are believed to increase bankruptcy costs, to create tax benefits, or to provide signals to the market regarding nonpublic information.

A more recent part of the finance literature examines the effect of capital market imperfections on the firm's actions. Market imperfections generate agency problems, which occur when individuals (principals) delegate decision making to agents and information regarding the agents' behavior is imperfect. Conflicts of interest among the principals and agents occur when principals and agents act in their self-interest and each forms rational expectations regarding future wealth. Costly financial contracts and various debt instruments that resolve these actual and potential conflicts are also examined in this literature. We review the literature concerning conflicts between bondholders and equity holders of for-profit firms, illustrating how resolution of such conflicts may affect the output of the nonprofit hospital. (We ignore the existence of conflicts between managers and equity holders because they are not directly linked to financing.) Although this finance literature rarely (if ever) directly addresses firms' decisions regarding the output of the firm, output is indirectly affected, through investment. 


\section{CONFLICTS BETWEEN BONDHOLDERS AND STOCKHOLDERS}

Debt financing in circumstances where shareholders are not responsible for the liabilities of the firm generates incentives for equity holders to accept high-risk projects, causing a transfer of wealth from bondholders to equity holders and incentives for equity holders to forgo new positive net present value (value-adding) investments. Jensen and Meckling (1976) describe how stockholders may expropriate the wealth of bondholders by increasing the risk of the firm. If stockholders issue debt to invest in a low-variance project (a low-risk project), they can alter the division of wealth from the project between bondholders and shareholders by investing instead in a high-variance (high-risk) project. This action lowers the value of debt because the new project is riskier and has a lower market value. The incentive for stockholders to do this can be understood by comparing equity to an option (technically a European call option) to buy back the entire firm from debt holders at the face value of the debt (Galai and Masulis 1976). The value of such an option increases with the variance (risk) of the cash flows generated by the underlying assets (Black and Scholes 1973). Thus, by switching to the higher-risk project, shareholders increase the value of their equity claims while decreasing the value of debt.

Once debt has been issued, stockholders have an incentive to ignore some profitable investments (Jensen and Meckling 1976; Myers 1977; Barnea, Haugen and Senbet 1981). When debt is supported entirely by future investment opportunities, only those investments that have a net present value greater than the debt payment will be accepted. Thus, some positive net present value (NPV) projects will be rejected. Since the value of the firm can be divided into the value of assets already in place and the present value of the firm's options to make future investments, a loss in firm value occurs (Myers 1977). Suboptimal investment may also occur when debt is issued against currently held assets (Bodie and Taggart 1978). New investments may not be made because some of the benefit partially accrues to bondholders in the form of a reduced default probability.

The conflict between bondholders and stockholders is particularly relevant to equity holders of nonprofit firms, because these equity holders are not motivated by monetary wealth maximization. If they value output of public goods, equity holders of the nonprofit firm will be especially prone to invest in projects that are risky for bondholders or to underinvest in positive NPV-projects. While it is possible for some bondholders to derive a degree of satisfaction from the provision of goods and 
services in lieu of interest and principle payments, this is not likely to be the general case.

\section{CONFLICT RESOLUTION}

Acting on the basis of self-interest and rational expectations regarding the potential behavior of equity holders, bondholders try to ensure repayment by altering the behavior of equity holders (bond issuers) in one or more of the following ways: (1) they write and monitor costly contracts (covenants); (2) they require bond insurance; or (3) they invest in debt instruments with certain characteristics.

\section{Bond Covenants}

Bond ratings are determined by the various rating agencies and are a leading determinant of the price (and, consequently, the interest rate) of the bond. Ratings are determined by examining the firm's operational history and monitoring current conditions of the firm and the marketplace. These historical and current data are used by rating agencies as predictors of future performance. Alternatively stated, the rating agencies assume either that the behavior of the firm will not change, or that any changes in behavior will be consistent with past behavior.

For some potential or actual bondholders, the predictors of performance used by the rating agencies may be insufficient inducements to buy or hold bonds. The available latitude of the behavior of the managers of the firm may be interpreted as involving more risk than the rating agencies predict. For these bondholders, guarantees may be required. Covenants are essentially guarantees on firm behavior. They are rules for selected activities of the firm and are also a determinant of the price of the bond. Hospitals issuing bonds may be required to maintain a specified debt service coverage ratio, maintain the facilities financed, pledge gross revenues to the repayment of the bond, not issue more debt, and the like (Baker 1985).

Through restricting the firm from activities that it would otherwise undertake, covenants can have an effect on firm behavior and performance. From the standpoint of the firm, covenants involve writing, monitoring, bonding, and enforcement costs, but may raise the price of the issue (decrease interest expenses) enough to cover costs (Kidwell, Sorensen, Wachowicz 1987).

The classic reference on bond covenants is Smith and Warner's (1979) description and analysis of the many problems of bondholder-stockholder conflict and the ways in which covenants are used as one mechanism to 
reduce this conflict. In particular, the study examines the covenants written to control four sources of conflict between bondholders and shareholders: (1) dividend payment, (2) claim dilution, (3) asset substitution, and (4) underinvestment. Bondholders are interested in ensuring that increases in dividends do not come at the expense of investment, which would lower bond values. Bondholders' claims are diluted and bond values decline when additional debt of the same or higher priority is issued. Substitution of higher variance/risk projects (assets) than those for which the bonds were originally issued lowers bond values as well. Finally, the value of bonds already issued falls when shareholders reject positive net present value projects because some of the benefits accrue to the bondholders.

Smith and Warner analyze data on 87 randomly selected public debt issues during 1974-1975. They find support for the hypothesis that there is a unique set of optimal financial contracts that maximizes the value of the firm. Specifically, covenants restrict the firm's (1) production-investment policy (35 percent of issues examined); (2) payment of dividends (23 percent of issues); (3) subsequent financing policy (91 percent of issues); (4) pattern of payoffs to bondholders; and (5) bonding activities. For example, firms under covenant agree not to sell certain assets, not to finance dividends by issuing additional stock or debt, or not to issue securities with higher priority; they may set up sinking funds for debt payments. All of these provisions are costly to the firm.

Brauer (1981) and Roberts and Viscione (1984) report that use of restrictive covenants increases bond prices (decreases interest expenses). Malitz (1986) attempts to explain the determinants and benefits of covenants by examining sinking-fund, dividend, and debt covenants on debentures issued from 1960-1980. She finds that a sinking-fund provision is the most frequent covenant, and that smaller firms, firms with high leverage positions, and firms that do not have longstanding debt issues in the market (meaning that there is less information about their history of expropriation of wealth) are most likely to benefit from covenants and to use them. Multiple discriminant analysis indicates that these factors correctly predict 82 percent of firms' covenants.

Thus, covenants, which resolve some conflicts between bondholders and shareholders, decrease interest expenses for firms by guaranteeing the behavior of the firm. Covenants may also change the behavior of NFP firms in several ways. First, bond covenants may restrict the ability of the NFP firm to invest in negative NPV projects that provide social benefits. Covenants are written partially to restrict investment in high-risk projects and to encourage investment in positive NPV projects. In addition, since cash flows must be maintained to meet debt service, NFP firms with debt 
may be less likely to provide charity care (payment of dividends). They may, however, increase their output of private goods. We know of no studies that have examined changes in firms' patterns of financing or behavior because of covenants.

\section{Bond Insurance}

Bond insurance, or "credit enhancement," improves the rating of the bond, perhaps providing access to AA or AAA credit ratings. The use of insurance for hospital bonds is increasing. In 1985, 40 percent of taxexempt health care bond issues were covered by insurance, compared to 27 percent in 1984. According to Claiborn (1985), relatively few firms (two to three) do most of the insuring, and they also have restrictive covenants. The Federal Housing Administration also offers insurance, often with fewer restrictions than other underwriters. Insurance, if thoughtfully purchased, is bought when the costs of the insurance and attached covenants outweigh the additional interest costs paid for bonds without these provisions. For a fee, insurance transfers the risk of default to the insurer. Due to the transfer of risk, the existence of insurance can affect firm behavior.

Insurance policies containing covenants will affect hospital output behavior in the manner just described. If covenants are not included, the insurance may stimulate additional risk-taking by the hospital. Again, as with covenants, we know of no studies that have examined changes in behavior due to the presence of insurance, nor have we found any studies that evaluate the tradeoffs between covenants and insurance.

\section{Financial Instruments}

Complex financial instruments may be necessary because markets cannot provide complete and costless solutions to agency problems. "In principle it would be possible for bondholders, by the inclusion of various covenants in the indenture provisions, to limit managerial behavior which results in reductions in the value of bonds" (Jensen and Meckling 1976, 337). Unfortunately, complete protection would require extremely detailed contracts that would be prohibitively expensive to write and monitor. Bondholders write covenants up to the point where the real marginal costs equal perceived marginal benefits. Beyond that point, agency problems can be controlled with various types of debt instruments. Barnea, Haugen, and Senbet (1980), Allen, Lamy, and Thompson (1987), Stultz and Johnson (1985), and Thatcher (1985) show how certain characteristics of debt instruments can resolve bondholder-shareholder conflicts. 
Barnea, Haugen, and Senbet (1980) illustrate how call provisions and maturity structures can resolve agency problems associated with risk incentives and forgone growth opportunities. They show that risk-shifting may be eliminated by adding a call provision to the bonds. If the price at which the option may be exercised is set appropriately, decreases in the value of the shareholders' call option caused by decreases in the value of debt more than offset any increases in shareholder claims resulting from risk-shifting.

They also discuss the resolution of the underinvestment problem both when debt matures after the future investment is made and when debt is entirely supported by a growth opportunity. They extend Bodie and Taggart's (1978) analysis, which ignores interest rate uncertainty and tax considerations, to resolve the agency problems. Here stockholders do not capture all the benefits of the investment; some accrue to the bondholders because the probability of default declines. Attaching a call provision so that managers can recall the debt at a stated price when the new investment decision is made counters some of the agency cost. Although this strategy may not restore the value of the firm to that of the all-equity financing case, issuance of callable debt is preferred by all firms over noncallable debt. It eliminates the need to write detailed covenants that try to specify the investment strategy in advance and to set up an elaborate monitoring system.

Allen, Lamy, and Thompson (1987), however, show that firms pay a price for short call periods. As the length of call protection increases, yields decrease. The same is not true of additional years of refunding protection. Bondholders do not believe that firms will not use other funds to call bonds and then issue new bonds. The bondholders are exposed to more interest rate risk if bonds are refunded early, because the rate they can earn when they reinvest their bond proceeds may be lower than the rate paid on their initial investment.

The underinvestment problem can be solved by financing new investment projects with secured debt (Stulz and Johnson 1985). Shareholders can sell the new bondholders a larger claim to the payoffs of the new investment and thereby reduce the transfer of wealth to existing bondholders when new investment occurs. Thatcher (1985) demonstrates empirically that firm characteristics that are proxies for high agency costs (e.g., a high debt-to-assets ratio) are associated with use of the option of early redemption. The flexibility of this option reduces the agency costs of debt associated with underinvestment and risk-shifting. Thus, bondholders act to increase the likelihood of repayment through altering the characteristics of financial instruments as well as by writing covenants and requiring issuing firms to purchase bond insurance. 
As described above, the addition of debt financing can affect the behavior of the NFP firm. These behavioral changes have implications for policy questions regarding whether NFP hospitals should issue debt, whether they should be reimbursed for the costs of debt, and whether that debt should be tax-exempt. Debt financing may move the behavior of NFP hospitals away from the provision of social goods, such as charity care, which are risky projects in the bondholders' view, and toward the provision of private outputs. It may also lead NFP hospitals away from negative NPV projects that provide social goods over a longer period of time because, from the bondholders' perspective, covenants and debt instruments resolve the underinvestment problem.

Wilson, Sheps, and Oliver (1982) argue that issuing debt increases the cost of care for reimbursers. However, they have been roundly criticized for ignoring the opportunity costs of equity (Foster 1983). Their argument actually focuses on additional costs of care to reimbursers because hospitals feel compelled to keep occupancy rates high and produce additional private outputs. Yet, since the return required on equity capital is still a matter of much debate, it may in fact be cheaper to use equity financing. Although Pauly (1986), for example, argues that the cost of retained earnings, or "forced contributions" is quite high, he claims that the cost of voluntary donations is low. In addition, the return required on equity is reduced by the tax benefits of donations and, perhaps, by any perceived extra social benefits. Until such debates are resolved, policymakers cannot determine whether NFPs should issue debt and whether they should encourage the use of debt through reimbursement of debt costs (Wedig, Sloan, Hassan, et al. 1988) or lack of reimbursement for equity costs (Conrad 1984).

On the other hand, issuing more debt increases the risk for equity holders, thereby increasing their required return. Equity holders for NFP firms may be especially sensitive to risk changes because they cannot sell their "shares" in a secondary capital market; thus, a return may also be required to compensate them for liquidity restrictions.

The papers reviewed in this section do not discuss the tax exemption of NFP debt. Tax exemption lowers the cost of debt to firms. Bondholders accept a lower return because they are not required to pay income taxes on interest income. As a result, tax-exempt debt may cause less deviation from the social good output preferences of equity holders. There may be less need to produce private outputs that create positive NPVs relative to those produced when debt is taxable. On the other hand, the lower cost of tax-exempt debt may increase the total amount of debt. Debt financing will be encouraged, especially if equity costs are higher than debt costs. Although most of these studies do not discuss health care firms directly, 
they do provide a conceptual basis from which to begin analyzing some important policy questions for NFP health care firms.

\section{CONCLUSION}

An understanding of the effects of various financing options on notfor-profit hospital behavior is important if public policy in this area is to be well formulated. This review has examined the sources of financing available to not-for-profit hospitals, and it has considered relationships between financing and the output of the hospital that might shed light on public policy.

Although we have reviewed a large number of papers from a wide variety of sources, it is clear that research to date has not solved, or in some cases even addressed, the many concerns and issues important to hospital financing. Should the tax deductibility of donations be allowed or extended? Would decreases in government financing-direct, indirect, or implicit-be replaced by private donations? Is there an appropriate policy to guide the profitability of hospitals, or to direct their retained earnings? And should tax exemption of hospital debt offerings, or the general tax-exempt status of hospitals, be continued? The literature has made inroads into each of these questions, but the answers are far from clear.

The literature suggests that the supply of donations is sensitive to prices, and that crowding-out and -in are only partial. Tax deductibility is certainly an important factor in determining the amount of donations. Government provision of financing reduces private financing, but removal of government financing is not expected to be associated with fully compensating increases in private donations. These findings indicate a role for the government in the financing of at least the public goods aspects of hospitals. However, the nature of the returns required by donors and the optimal levels of government financing remain to be examined.

Along related lines, the earning of profits by the not-for-profit hospital has long been debated. Profit potential enables cross subsidization of some patients. Cross subsidization may or may not be an appropriate role for NFP hospitals, but it is a role that they have assumed for much of their history-and a role consistent with some theories of the NFP firm. The existence of retained earnings does imply that some opportunities to provide additional charity care or another social good have been forgone, presumably in exchange for the ability to provide more in the future. The appropriateness of using these retained earnings for long-term financing has not been fully explored.

Tax-exempt debt allows hospitals to use the debt market, which 
otherwise might not be available at a reasonable price given the competition of for-profit firms in the ordinary debt market. The use of debt frequently involves direct restrictions on hospital behavior, through covenants, or indirect restrictions, through insurance or contracting provisions. The extent to which behavior is actually restricted or changed has not been investigated. While there is much speculation that hospitals have been diverted from their missions with the increase in debt financing, this has not been shown through empirical research. Policies that restrict tax-exempt debt should be based on an understanding of the effects of debt financing. Such an understanding does not yet exist.

Before these important empirical questions can be researched, theoretical models of the relationship between financing and output must be improved. Little theoretical work that integrates donor motivations with active firm behavior has been pursued (Rose-Ackerman 1982; Pauly 1987a). Since financing is expected to affect output, and output to affect financing, the role of the return expected by donors must be explicitly modeled. Although Long (1976), Conrad (1984), Silvers and Kauer (1986), and Pauly (1986) address this issue, they present conflicting and incomplete arguments. For example, questions concerning whether donors attach extra nonmonetary value to social outputs, whether there are conflicts between donors and managers, and the role of retained earnings are discussed incompletely or not at all. Moreover, none of the authors of the papers reviewed is careful to separate types of donations. It is likely that donors give to purchase output in the current period, to contribute lumpsum amounts for operations in the current period, or to invest in the firm for future periods. These types of donations must be distinguished if return rates are to be determined accurately. Finally, the role of debt financing is discussed only to a limited degree. The full ramifications of debt financing on behavior have yet to be modeled.

We have attempted to highlight those areas that clearly call for future research, but we expect that the research community will not be limited to our ideas and will find new and innovative approaches to the issues. Much of the literature on hospital financing is very recent and expanding rapidly. The advancement of this literature, it is hoped, will lead to more informed financing policy.

\section{REFERENCES}

Abrams, B. A., and M. D. Schmitz. "The Crowding-Out Effect of Governmental Transfers on Private Charitable Contributions: Cross-Section Evidence." $\mathrm{Na}$ tional Tax Journal 37, no. 4 (1984): 563-68.

Allen, D. S., R. E. Lamy, and G. R. Thompson. "Agency Costs and Alternative 
Call Provisions: An Empirical Investigation." Financial Management 16, no. 4 (1987): 37-44.

Anderson, G., J. Erickson, and S. Feigenbaum. "Examining the Relationship between Capital Investment and Hospital Operating Expenditures." Reviezv of Economics and Statistics 64 (November 1987): 709-13.

Ashby, J. L., Jr. "The Impact of Hospital Regulatory Programs on Per Capita

Costs, Utilization, and Capital Investment." Inquiry 21 (Spring 1984): 45-59. Baker, B. J. "Restrictive Covenants in Hospital Bond Financing." Topics in Health Care Financing 11, no. 4 (1985): 43-49.

Barnea, A., R. A. Haugen, and L. M. Senbet. Agency Problems and Financial Contracting. Englewood Cliffs, NJ: Prentice-Hall, 1985. . "A Rationale for Debt Maturity Structure and Call Provisions in the Agency Theoretic Framework." Journal of Finance 35 (December 1980): 1223-34. . "Market Imperfections, Agency Problems, and Capital Structure: A

Review." Financial Management 10, no. 2 (1981): 7-22.

Baumol, W. J. Business Behavior, Value, and Growth. New York: Macmillan, 1959. Becker, G. "A Theory of Social Interactions." Journal of Political Economy 82 (November/December 1974): 1063-94.

Bentkover, J. D., F. A. Sloan, F. G. Feeley, C. Campbell, and L. Firth. "Hospital Capital and Operating Costs." Advances in Health Economics and Health Services Research. 5 (1984): 213-36.

Bergstrom, T., L. Blume, and H. Varian. "On the Private Provision of Public Goods." Journal of Public Economics 29 (February 1986): 25-50.

Black, F, and M. Scholes. "The Pricing of Options and Corporate Liabilities." Joumal of Political Economy 81 (May/June 1973): 637-54.

Bodie, Z., and R. A. Taggart. "Future Investment Opportunities and the Value of the Call Provision on a Bond." Journal of Finance 33 (September 1978): 1187-1200.

Bradley, M., G. A. Jarrell, and E. H. Kim. "On the Existence of and Optimal Capital Structure: Theory and Evidence." Journal of Fintance 39 (July 1984): 857-80.

Brauer, G. "Evidence of the Market Value of Me-First Rules." Financial Management 10 (Spring 1981): 11-18.

Claiborn, S. A. "Alternative Financing Approaches for Health Care Institutions." Topics in Health Care Financing 11, no. 4 (Summer 1985): 33-41.

Clarkson, K. "Some Implications of Property Rights in Hospital Management." Journal of Law and Economics 15, no. 2 (1972): 363-76.

Cohodes, D. R. "Which Will Survive? The $\$ 150$ Billion Capital Question." Inquiry 20, no. 1 (1983): 5-11.

Cohodes, D. R., and B. M. Kinkead. Hospital Capital Formation in the 1980s. Baltimore, MD: Johns Hopkins University Press, 1984.

Conrad, D. A. "Returns on Equity to Not-for-Profit Hospitals: Theory and Implementation." Health Services Research 19, no. 1 (April 1984): 41-63.

Danzon, P. M. "Hospital Profits: The Effects of Reimbursement Policies." Journal of Health Economics 2, no. 1 (1982): 29-52. 
Davis, K. "Economic Theories of Behavior in Non-Profit Private Hospitals." Economic and Business Bulletin 24, no. 4 (1972): 12-135.

Dittman, D. A., and R. C. Morey. "Optimal Pricing of Hospital Services." Inquiry 18, no. 4 (1981): 311-21.

Dunkelberg, J. S., R. W. Furst, and R. L. Roenfeldt. "State Rate Review and the Relationship between Capital Expenditures and Operating Costs." Inquiry 20, no. 3 (Fall 1983): 240-47.

Feenberg, D. "Are Tax Price Models Really Identified: The Case of Charitable Giving." National Tax Journal 60, no. 4 (1987): 629-34.

Feldstein, M. S. "Hospital Cost Inflation: A Study of Non-Profit Price Dynamics." American Economic Review 61, no. 5 (1971): 853-72.

Feldstein, M. S., and A. Taylor. "The Income Tax and Charitable Contributions." Econometrica 44 (November 1976): 1201-22.

Foster, R. W. "Letter to the Editor." Newv England Journal of Medicine 308, no. 17 (1983): 1036.

Galai, D., and R. Masulis. "The Option Pricing Model and the Risk Factor of Stock." Journal of Financial Economics 4 (January-March 1976): 53-81.

Harris, J. E. "Pricing Rules for Hospitals." Bell Journal of Economics 10, no. 1 (1979): 224-43.

Herzlinger, R., and W. S. Krasker. "Who Profits from Nonprofits?" Harvard Business Review 63 (January/February 1987): 93-106.

Institute of Medicine. For Profit Enterprise in Health Care. Washington, DC: National Academy Press, 1986.

Jacobs, P. "A Survey of Economic Models of Hospitals." Inquiry 11, no. 2 (1974): 83-97.

James, E. "How Nonprofits Grow: A Model." Journal of Policy Analysis and Management 2 (Spring 1983): 350-65.

Jensen, M., and W. Meckling. "The Theory of the Firm: Managerial Behavior, Agency Costs and Ownership Structure." Joumal of Financial Economics 4 (June 1976): 305-60.

Joseph, H. "On Economic Theories of Hospital Behavior." Joumal of Economics and Business 27, no. 4 (1974): 69-74.

Kidwell, D. S., E. H. Sorensen, and J. M. Wachowicz. "Estimating the Signaling Benefits of Debt Insurance: The Case of Municipal Bonds." Joumal of Financial and Quantitative Analysis 22, no. 3 (1987): 299-314.

Lave, J. R., and L. B. Lave. The Hospital Construction Act: An Evaluation of the Hill-Burton Program, 1948-1973. Washington, DC: The American Enterprise Institute, 1974.

Lee, M. L. "A Conspicuous Production Theory of Hospital Behavior." Southern Economic Journal 38, no. 1 (1971): 48-58.

Long, H. "Asset Choice and Program Selection in a Competitive Environment, Part 1." Healthcare Financial Management 12, no. 7 (July 1982a): 40-54. "Asset Choice and Program Selection in a Competitive Environment, Part 2." Healthcare Financial Management 12, no. 8 (August 1982b): 34-50. 
"Valuation as a Criterion in Not-for-Profit Decision-Making." Health Care Management Review 1, no. 1 (1976): 34-52.

Malitz, I. "On Financial Contracting: The Determinants of Bond Covenants."

Financial Management 15, no. 2 (1986): 18-25.

Myers, S. C. "Determinants of Corporate Borrowing." Journal of Financial Economics 5 (November 1977): 147-76.

Navarro, P. "Why Do Corporations Give to Charity?" Journal of Business 61, no. 1 (1988): 65-93.

Newhouse, J. "A Model of Physician Pricing." Southern Economic Joumal 37, no. 2 (1970): 174-83.

Pauly, M. V. "Nonprofit Firms in Medical Markets." American Economic Review 77, no. 2 (1987a): 257-62.

. "Paying Returns on Equity to Not-for-Profit Hospitals-Some Further Thoughts." Health Services Research 22, no. 2 (1987b): 271-75.

. "Returns on Equity for Not-for-Profit Hospitals." Health Services Research 21, no. 1 (1986): 1-16.

Pauly, M., and M. Redisch. "The Not-for-Profit Hospital as a Physicians' Cooperative." American Economic Review 63, no. 1 (1973): 87-97.

Posnett, J., and T. Sandler. "Joint Supply and the Finance of Charitable Activity." Public Finance Quarterly 14 (April 1986): 209-22.

Prospective Payment Assessment Commission. Medicare Prospective Payment and the American Health Care System: Report to the Congress. Department of Health and Human Services. Washington, DC: Government Printing Office, 1987.

Reece, W. S. "Charitable Contributions: New Evidence on Household Behavior." American Economic Reviezv 69, no. 1 (1979): 142-51.

Reece, W. S., and K. D. Zieschlang. "Consistent Estimation of the Impact of Tax Deductibility on the Level of Charitable Contributions." Econometrica 53, no. 2 (1985): 271-93.

Rice, R. "Analysis of the Hospital as an Economic Organism." Modern Hospital 97, no. 4 (1966): 91-98.

Roberts, G., and J. Viscione. "The Impact of Seniority and Security Covenants on Bond Yields: A Note." Jountal of Finance 39: (December 1984): 1597-1602. Roberts, R. "A Positive Model of Private Charity and Public Transfers." Journal of Political Economy 92 (February 1984): 136-48.

Rose-Ackerman, S. "Charitable Giving and 'Excessive' Fundraising." Quarterly Journal of Economics 77 (May 1982): 193-212.

"Do Government Grants to Charity Reduce Private Donations." In Nonprofit Fims in a Three Sector Economy. Edited by M. J. White. Washington, DC: The Urban Institute, 1983.

. "Ideals versus Dollars: Donors, Charity Managers, and Government Grants." Joumal of Political Economy 95 (July 1987): 810-23.

Schiff, J. "Does Government Spending Crowd Out Charitable Contributions?" National Tax Journal 38 (December 1985): 535-46.

Silvers, J. B., and R. T. Kauer. "Returns on Equity for Not-for-Profit Hospitals: Some Comments." Health Services Research 21, no. 1 (1986): 21-28. 
Simon, H. A. "Rationality as a Product and Process of Thought." American Economic Review 68, no. 2 (1978): 1-16.

Sloan, F. A., and B. Steinwald. "Effects of Regulation on Hospital Costs and Input Use." Journal of Law and Economics 23, no. 1 (1980a): 27-55. Regulation and Hospital Costs. Lexington, MA: Lexington Books, D.C. Heath Company, 1980b.

Sloan, F. A., and E. R. Becker. "Internal Organization of Hospitals and Hospital Costs." Inquiry 18, no. 4 (1981): 224-39.

Sloan, F. A., and R. A. Vraciu. "Investor-Owned and Not-for-Profit Hospitals: Addressing Some Issues." Health Affairs 12 (Spring 1983): 25-37.

Sloan, F. A., J. Valvona, M. Hassan, and M. Morrisey. "Cost of Capital to the Hospital Sector." Joumal of Health Economics. 7, no. 1 (1988): 25-45.

Sloan, F. A., M. Morrisey, K. Cotter, and M. Hassan. "The Demise of Hospital Philanthropy." Unpublished manuscript. Vanderbilt University, 1986, Nashville, Tennessee.

Smith, C. W., and J. B. Warner. "On Financial Contracting: An Analysis of Bond Covenants." Journal of Financial Economics 7 (June 1979): 117-61.

Steinberg, R. "The Revealed Objective Functions of Nonprofit Firms." RAND Joumal of Economics 17, no. 4 (1986): 508-26.

"Voluntary Donations and Public Expenditures in a Federalist System." American Economic Review 77, no. 1 (1987): 24-36.

Stulz, R. M., and H. Johnson. "An Analysis of Secured Debt." Journal of Financial Economics 14 (December 1985): 501-21.

Sugden, R. "Reciprocity: The Supply of Public Goods through Voluntary Contributions." The Economic Journal 94 (December 1984): 772-87.

Taggart, R. A., Jr. "Rate-of-Return Regulation and Utility Capital Structure Decisions." Journal of Fintance 36 (May 1981): 383-93.

Thatcher, J. S. "The Choice of Call Provision Terms." Journal of Finance 40 (June 1985): 549-61.

Titman, S., and R. Wessels. "The Determinants of Capital Structure Choice." Journal of Finance 43, no. 1 (1988): 1-19.

Wedig, G., F. A. Sloan, M. Hassan, and M. Morrisey. "Capital Structure, Ownership, and Capital Payment Policy: The Case of Hospitals." Journal of Finance 43, no. 1 (1988): 21-40.

Weisbrod, B. A., and N. D. Dominguez. "Demand for Collective Goods in Private Nonprofit Markets: Can Fundraising Expenditures Help to Overcome Free-Rider Behavior?" Journal of Public Economics 30 (June 1986): 83-95.

Weisbrod, B. A., ed. The Voluntary Nonprofit Sector. Lexington, MA: Lexington Books, 1977.

Weiss, J. H. "Can Donations Reduce a Donor's Welfare?" Public Choice 47, no. 2 (1985): 337-47.

Wilson, G., C. G. Sheps, and T. R. Oliver. "Effects of Hospital Revenue Bonds on Hospital Planning and Operations." New England Journal of Medicine 307, no. 23 (1982): 1426-30. 
Williamson, O. "Markets and Hierarchies." American Economic Review 63, no. 2 (1973): 316-25.

Young, D. W., and R. B. Saltman. "Prospective Reimbursement and the Hospital Power Equilibrium: A Matrix-Based Management Control System." Inquiry 20, no. 2 (1983): 20-33. 